\title{
PENYESUAIAN DIRI PEREMPUAN BALI TURUN KASTA
}

\author{
I Gusti Ayu Agung Istri Risna Prajna Devi ${ }^{1 *}$, Nurchayati ${ }^{1}$ \\ ${ }^{1}$ Universitas Negeri Surabaya, Indonesia \\ *e-mail: ayurisnaprajna@gmail.com
}

\begin{abstract}
Abstrak
Penelitian ini mengkaji penyesuaian diri (adjustment) perempuan Bali yang menikah dengan lelaki berkasta lebih rendah dari dirinya sehingga mengalami nyerod (turun kasta). Pendekatan kualitatif ini menggunakan metode studi kasus. Data dikumpulkan melalui wawancara semi-terstruktur. Data dianalisis secara naratif. Partisipan penelitian ini adalah lima perempuan Hindu-Bali yang telah menikah lintas-kasta minimal 10 tahun dan turun kasta dari Ksatria ke Sudra. Studi ini menemukan bahwa dalam pernikahan beda kasta tersebut terjadi penyesuaian diri di beberapa bidang, seperti hubungan dengan pasangan, manajemen konflik, hubungan dengan keluarga besar, serta hubungan dengan status sosialnya. Faktor pendukung penyesuaian diri perempuan nyerod adalah fleksibilitas, dukungan, dan penerimaan dari keluarga asal dan keluarga suami. Sebaliknya, trauma masa lalu, rasa penyesalan, perlakuan tidak adil dari orang tua, dan tuntutan segera memiliki anak menjadi faktor yang menghambat penyesuaian diri.
\end{abstract}

Kata kunci: Penyesuaian Diri; Nyerod; Turun Kasta; Perempuan Bali

\begin{abstract}
This qualitative case study examined the adjustment challenges and strategies of Hindu-Balinese women who have "married down casted" (nyerod). Research data was collected through semi-structured interviews. The data is analyzed narratively. Participants in the study included five Hindu-Balinese women of the Kshatriya caste who have been married to men of the Sudra caste for at least ten years and have been down casted to their husband level. The study revealed that these women faced and responded to adjustment challenges such as relationship with a partner, conflict management, extended family, and social status in their intercaste marriage. Flexibility, support, and acceptance from the husband's family and family are contributing factors to intercaste marriage adjustment. In contrast, past trauma, remorse, unfair treatment of parents, and the immediate demands of having children are factors that hinder intercaste marriage adjustment.
\end{abstract}

Keywords: Marital Adjustment; Nyerod; Down Casted; Balinese Women

This is an open access article under the CC BY-SA license.

Copyright (C) 2021 by Author. Published by Universitas Pendidikan Ganesha.

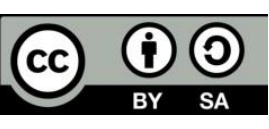

\section{PENDAHULUAN}

Masyarakat Bali-khususnya yang beragama Hindu—hingga saat ini taat menjalankan adat mereka. Salah satu unsur adat yang masih bertahan adalah sistem stratifikasi sosial berbentuk kasta: kasta tertinggi adalah triwangsa (tiga kasta) yakni Brahmana, 
Ksatria dan Waisya. Sudra (jaba) adalah kasta paling rendah. Penerapan sistem kasta secara ketat di kalangan masyarakat Hindu-Bali ini mempertajam hierarki berbasis keturunan atau gelar (Gautama, 2005).

Masyarakat Bali menganut sistem patrilineal yaitu mengikuti garis keturunan laki-laki (Budiana, 2014). Artinya, kasta seseorang ditentukan berdasarkan kasta kepala rumah tangga atau pihak laki-laki. Jika seorang perempuan menikah dengan laki-laki berkasta lebih tinggi, maka derajat perempuan itu akan naik. Sebaliknya, jika mereka menikah dengan laki-laki yang kastanya lebih rendah, ia akan turun kasta (nyerod). Seperti yang terjadi pada para perempuan Hindu di India (Deviga \& Visalakshi, 2020), pernikahan turun kasta bagi perempuan Hindu-Bali mengakibatkan mereka kehilangan hak-hak sosialnya, apa pun status dan tingkat pendidikannya.

\section{Perempuan}

nyerod menanggung beberapa konsekuensi sosial. Pertama, proses pernikahannya melewati tahap lamaran. Secara diamdiam, calon mempelai laki-laki menjemput calon mempelai perempuan atau biasa dikenal dengan istilah mapadik. Kedua, keluarga mempelai perempuan tidak boleh mengadakan pesta pernikahan. Ketiga, Kedua orang tua mempelai perempuan tidak diperkenankan menghadiri rangkaian upacara pernikahan putri mereka (Oka, 2000). Keempat, setelah menikah, seorang perempuan nyerod harus berkomunikasi dengan keluarga asalnya secara hierarkis. la harus menyapa para anggota keluarga asalnya dengan kata tu atau ratu sebagai sapaan hormat kepada kasta yang lebih tinggi. Kelima, bahkan setelah bercerai, perempuan nyerod tidak akan memperoleh kembali kasta asalnya (Ariani, 2010). Keenam, pernikahan nyerod melibatkan sebuah upacara khusus yang disebut Pati Wangi untuk menghapus keharuman yang melekat pada kasta asal (Martha, 2018).

Fenomena nyerod berpotensi menimbulkan masalah, baik konflik keluarga/masyarakat maupun masalah psikologis di kalangan pelakunya. Hasil wawancara peneliti dengan tokoh masyarakat salah satu desa di Bali mengungkapkan bahwa setidaknya ada dua kasus konflik besar di desa tersebut akibat nganten nyerod (pernikahan beda kasta) hingga pada akhirnya mengharuskan perangkat desa turun tangan: keluarga inti perempuan menginginkan adanya proses mamadik (melamar), namun keinginan tersebut ditolak oleh keluarga besar dan masyarakat sekitar. Nyerod juga berpotensi menimbulkan masalah psikologis. Hilangnya beberapa hak sosial merusak prospek kehidupannya perempuan nyerod. Beban ini menuntut para perempuan melakukan penyesuaian diri secara ganda: (1) adaptasi pada status baru sebagai istri, ibu, menantu dan saudara ipar, dan (2) adaptasi pada kondisi turun kasta. Atas kondisi tersebut di atas, kajian tentang penyesuaian diri di kalangan perempuan nyerod beserta faktor-faktor pendukung dan penghambatnya penting dilakukan. Pengetahuan ini bermanfaat, utamanya untuk meminimalisir masalah psikologis di kalangan para pelakunya.

Jurnal IImu Sosial dan Humaniora| 369 
Secara umum, penyesuaian diri (adjustment) dapat dipahami sebagai upaya mencapai titik temu optimal antara tuntutan lingkungan dan keadaan diri sendiri (Yikar et al., 2019). Dengan kata lain, penyesuaian diri adalah cara seseorang beradaptasi dengan efektif (Weiten et al., 2018). Secara khusus, dalam menjalani kehidupan berumah tangga, terdapat empat jenis penyesuaian diri, yang meliputi penyesuaian diri dengan pasangan, penyesuaian diri secara seksual, penyesuaian diri secara finansial, dan penyesuaian diri dengan keluarga pasangan (Hurlock, 2014).

Penyesuaian diri dengan pasangan diibaratkan dengan jitu dalam peribahasa Inggris lama,"Birds of a feather flock together." Sebagaimana terkonfirmasi dalam studi-studi tentang hubungan dekat, peribahasa ini menandaskan bahwa individu cenderung bergaul dengan orang-orang yang mirip dengannya (Santrock, 2018). Pernikahan berarti bertemunya dua masa lalu dan dua kebiasaan sehari-hari yang berbeda dan karenanya tak jarang menimbulkan frustrasi (Hurlock, 2014). Pernikahan mendorong istri dan suami untuk memadukan konsep diri mereka dengan skema budaya gender yang berlaku di tempat mereka bermukim (Snyder \& Lopez, 2012). Pasangan suami-istri dapat disebut kompak ketika mereka telah mampu mengerti makna dan fluktuasi emosi masing-masing dari waktu ke waktu (Weiten et al., 2018).

Setelah menikah, orang harus menyesuaikan dirinya dengan keluarga pasangan sebab menikah berarti menyatukan bukan hanya dua individu tetapi juga dua keluarga. Sebelum menikah, penyesuaian diri berarti memandang diri sendiri dan masyarakat secara kolektivis (Santrock, 2018). Hubungan kolektivis merupakan sebuah keterikatan individu dengan identitas kelompoknya. Keterikatan ini menjadi kerangka sosial yang setiap bagian di dalamnya wajib menjaga kepentingan satu sama lain. Setelah menikah, makna penyesuaian diri bergeser menjadi penyesuaian kepada kehidupan seharihari dalam lingkungan keluarga tempat kita tinggal. Setiap keluarga memiliki budaya, etika dan tradisi masing-masing (Santrock, 2018).

Fenomena turun kasta akibat pernikahan di kalangan perempuan Bali sudah dikaji oleh beberapa penelitian terdahulu. Aspek yang menjadi fokus kajian dalam riset-riset tersebut meliputi masalah konflik psikologis yang mereka alami akibat perubahan status sosial (Alandari \& Muti'ah, 2019) dan kesejahteraan psikologis mereka setelah menikah dan turun kasta (Arisandi, 2015). Penelitian lain mengkaji penyesuaian diri perempuan dari golongan triwangsa yang turun kasta karena pernikahan (Mahardini \& Tobing, 2017). Sama halnya dengan penelitian Mahardini dan Tobing (2017), penelitian ini mengkaji aspek penyesuaian diri di kalangan perempuan Hindu Bali yang turun kasta karena pernikahan. Namun demikian, penelitian ini memiliki beberapa perbedaan dengan penelitian Mahardini dan Tobing (2017). Pertama, berbeda halnya dengan Mahardini dan Tobing yang berfokus dinamika penyesuaian diri di kalangan perempuan yang turun kasta, penelitian ini tidak hanya melihat aspek-aspek penyesuaian diri namun

Jurnal IImu Sosial dan Humaniora | 370 
juga menggali faktor yang mendukung dan menghambat proses penyesuaian diri. Kedua, partisipan penelitian Mahardini dan Tobing adalah perempuan dari tiga kasta berbeda (Waisya, Brahmana, dan Ksatria), sedang partisipan penelitian ini berasal dari satu kasta spesifik, yaitu Ksatria. Ketiga, penelitian ini menggunakan metode studi kasus sedangkan penelitian Mahardini dan Tobing menerapkan fenomenologi.

Berdasarkan paparan di atas, penelitian ini hendak mengkaji penyesuaian diri di kalangan perempuan Hindu-Bali yang turun kasta karena pernikahan serta faktor-faktor apa saja yang mendukung dan menghambat proses penyesuaian diri tersebut. Selaras dengan sifat pertanyaan riset yang ingin dijawab, penelitian ini lebih mengutamakan sudut pandang perempuan.

\section{METODE}

Riset kualitatif ini bermetodekan studi kasus. Hodgetts dan Stolte (2012) menandaskan bahwa studi kasus dapat menyingkapkan dan memahami berbagai fenomena sosial penting, seperti proses-proses sosial yang bekerja dalam sebuah komunitas pada seorang individu, sebuah peristiwa atau transformasi. Peneliti memilih studi kasus karena metode ini tampaknya berpotensi kuat untuk membantu mencapai pemahaman mendalam atas penyesuaian diri perempuan nyerod (turun kasta).

Data dikumpulkan melalui partisipan penelitian ini yaitu lima orang perempuan Hindu-Bali berkasta Ksatria yang telah nyerod menjadi Sudra akibat pernikahan antarkasta selama rentang waktu 10-20 tahun. Tabel 1 menyajikan informasi kunci tentang mereka berdasarkan usia sekarang, umur ketika menikah dan lamanya menikah.

Tabel 1. Kategori Partisipan

\begin{tabular}{|l|l|l|l|}
\hline $\begin{array}{c}\text { Nama } \\
\text { Samaran }\end{array}$ & $\begin{array}{c}\text { Usia } \\
\text { (tahun) }\end{array}$ & $\begin{array}{c}\text { Usia } \\
\text { Menikah } \\
\text { (tahun) }\end{array}$ & $\begin{array}{c}\text { Usia } \\
\text { Pernikahan } \\
\text { (tahun) }\end{array}$ \\
\hline $\begin{array}{l}\text { Agung } \\
\text { Dewi }\end{array}$ & 48 & 28 & 20 \\
\hline $\begin{array}{l}\text { Agung } \\
\text { Kencana }\end{array}$ & 43 & 28 & 15 \\
\hline Gusti Ani & 44 & 26 & 18 \\
\hline $\begin{array}{l}\text { Gusti } \\
\text { Tari }\end{array}$ & 35 & 24 & 11 \\
\hline $\begin{array}{l}\text { Gusti } \\
\text { Meitri }\end{array}$ & 36 & 26 & 10 \\
\hline
\end{tabular}

*Nama di atas adalah nama samaran

Data dikumpulkan menggunakan teknik wawancara mendalam (in-depth interview), yaitu dengan menggali informasi secara bebas, terbuka dan mendalam dengan senantiasa berfokus pada topik riset (Denzin \& Lincoln, 2017). Wawancara berlangsung secara semiterstruktur yaitu tanya-jawab antara peneliti dan partisipan berlandaskan pedoman yang telah disusun (Merriam \& Tisdell, 2016). Untuk menangkap dan menyimpan data wawancara tatap muka dan via telepon, peneliti merekam percakapan dengan aplikasi recorder pada smartphone sambil membuat melakukan pencatatan dengan tulisan tangan (Creswell, 2014).

Sebagai adaptasi pada kondisi di masa pandemi COVID-19, yang mengharuskan masyarakat berdiam diri di rumah, peneliti banyak mengandalkan komunikasi lisan dan tertulis melalui whatsapp. Wawancara dilakukan 
melalui whatsapp call dan di rumah partisipan dengan tetap mematuhi protokol kesehatan: wawancara dengan tiap responden dilakukan dengan whattsapp call sebanyak 2-3 kali dengan durasi 25-60 menit sedang wawancara langsung dilakukan satu kali dengan durasi 40-60 menit. Wawancara dilakukan pada bulan Juni-September 2020.

Analisis data dalam penelitian merujuk pada Creswell (2014) yaitu menuliskan secara tematis kronologi perempuan nyerod. Untuk menguji keabsahan data, digunakan teknik member checking dan melakukan triangulasi atas sumber data. Member checking mengharuskan peneliti melakukan wawancara lebih lanjut dalam dua sampai tiga kali untuk memberikan partisipan kesempatan untuk memberikan komentar kritis atas hasil penelitian (Creswell, 2014). Dalam riset ini, triangulasi data melibatkan wawancara dengan significant others, yakni suami partisipan. Tujuannya adalah untuk menjamin akurasi data berdasarkan sudut-sudut pandang yang berbeda. Hasil-hasil wawancara dengan significant others dijadikan penguat dalam penarikan simpulan penelitian.

\section{HASIL DAN PEMBAHASAN}

\section{Kasus 1 - Agung Dewi}

Keputusan Menikah Nyerod

Pertemuan Agung Dewi dengan Made Tresna berawal dari SMA. Agung Dewi dan Made Tresna adalah teman sekelas dan Made Tresna duduk di belakang Agung Dewi. Awalnya, Made Tresna adalah teman belajar, tetapi lambat-laun berubah menjadi kekasih Agung Dewi. Hubungan asmara mereka berjalan delapan tahun sampai akhirnya Agung Dewi dan Made Tresna menikah.

[kasta] tidak terlalu dianggap suatu hal yang penting [bagi keluarga] sih. Sama saja semuanya. Apalagi ibu tante kan dari bukan triwangsa ya, jadi kasta itu bukan suatu hal yang menjadi penilaian mutlak sih di keluarga tante (Agung Dewi, 7 Juli 2020).

Berdasarkan latar belakang kedua orang tua yang berasal dari kasta berbeda yaitu ayah Ksatria dan ibu Sudra, kasta tidak dipandang secara fundamental oleh orang tua Agung Dewi. Hal ini membuat Agung Dewi dan Made Tresna berani memutuskan untuk melanjutkan hubungan ke jenjang yang lebih tinggi yaitu pernikahan. Pada umur 28 tahun, Agung Dewi menikah dengan Made Tresna. Ungkapan niat Agung Dewi dan Made Tresna pun disambut baik oleh keluarga kedua belah pihak.

\section{Penyesuaian Diri dengan Status Sosial Baru}

Sebagai perempuan yang nyerod, Agung Dewi harus menjalani proses malaib (berlari) di malam hari. Tiga hari setelah malaib, yakni di hari upacara pernikahan, Agung Dewi sedih, bahkan menangis, ketika benar-benar mengalami dan menyadari bahwa orang tuanya tidak dapat hadir di hari bahagianya dan hanya digantikan oleh bibi dan adik-adiknya. Dalam wawancara dengan Made Tresna (9 Juli 2020) terungkap bahwa Agung Dewi sempat merasa sedih dan kesedihan itu ditepis setelah ia menyadari bahwa itulah konsekuensi yang harus diterima.

Dalam masyarakatnya, Agung Dewi memang mengalami perbedaan setelah ia nyerod. Jika sebelum ia 
menikah, rekan-rekan kerja dan para warga di komunitasnya berkomunikasi dengannya dalam bahasa Bali halus, namun setelah ia menikah, mereka bercakap-cakap dengannya dalam bahasa Bali sehari-hari:

Kalau dulu teman-teman maupun orang di desa pakai bahasa halus singgih tapi setelah menikah jadi biasa saja bahasanya. Dulu juga sering berbagi buah atau jajan surudan [sesajen setelah sembahyang], sekarang sudah gak bisa (Agung Dewi, 26 September 2020).

Meskipun terdapat perbedaan perlakuan yang diterima dari lingkungan sekitarnya, hal ini tidak membuat Agung Dewi menyesali keputusannya menikah. la menyadari bahwa itu adalah konsekuensi yang harus diterimanya.

\section{Penyesuaian Diri dalam Pernikahan}

Sebagai pasangan yang telah menjalani masa pacaran delapan tahun sebelum menikah, Agung Dewi dan Made Tresna pun harus menyesuaikan diri dengan krisis dalam pernikahan mereka salah satunya adalah ketika Agung Dewi berduka akibat wafatnya putri pertamanya di hari kelahirannya. Musibah ini membuat Agung Dewi berkabung cukup lama dan sensitif sehingga butuh waktu sekitar dua tahun untuk menyesuaikan diri dengan perannya sebagai seorang istri:

[...] pas anak pertama meninggal pas tante lahiran. Ya sering ambil waktu sendiri, ngurung diri. Tapi ya suami tetap menemani. Sudah pada ikhlas, tante yang susah ikhlasnya (Agung Dewi, 26 September 2020).

Agung Dewi dan Made Tresna telah berhasil mencapai penyesuaian diri finansial. Indikatornya adalah bahwa mereka bersama-sama membiayai putra-putrinya, mengasuransikan para anggota keluarga, berhasil memenuhi kebutuhan sandang, pangan dan papan, serta saling terbuka perihal kondisi keuangan masing-masing.

"Astungkara sejauh ini gak pernah sih [mengalami permasalahan finansial], sejauh ini cukup untuk memenuhi kebutuhan keluarga", begitulah ungkapan Agung Dewi (7 Juli 2020).

Sukses Agung Dewi dan Made Tresna dalam beradaptasi secara finansial menurunkan tingkat ketegangan dan konflik dalam rumah tangga mereka.

Sedikit pun Agung Dewi tak menyesali keputusannya untuk menikah turun kasta. la yakin bahwa ia dan suaminya akan bisa saling membahagiakan. Keyakinan ini membuatnya mampu menyesuaikan diri dengan segala tantangan yang menghampiri kehidupan rumah tangganya.

Agung Dewi berpandangan bahwa cinta adalah penerimaan dan ketika mencintai seseorang, kita harus siap menerima segala kondisi, seperti senang dan sedih, serta pasang dan surut. Hal ini memantapkan hatinya untuk menerima pinangan dengan konsekuensi yang sudah diantisipasi.

Faktor Pendukung Penyesuaian Diri: Fleksibilitas Keluarga Asal dan Suami

Selain menyatukan dua insan, pernikahan juga memadukan dua keluarga. Sama-sama memiliki keluarga berpandangan terbuka dan sangat toleran, Agung Dewi diterima dan diperlakukan dengan baik oleh keluarga Made Tresna. Di keluarga Agung Dewi tidak diberlakukan sebuah aturan turun- 
temurun dan tak tertulis bagi masyarakat Hindu-Bali, yaitu bahwa perempuan nyerod harus memanggil orang yang berkasta di atasnya (termasuk keluarga asalnya sendiri) dengan sapaan tu atau ratu. Bertolak belakang dengan aturan ini, Agung Dewi diperkenankan untuk memanggil para anggota keluarga asalnya dengan cara sama seperti sebelum ia menikah.

Masih sering kumpul. Sama adik-adik, misal pas ultah salah satu dari kita ya kumpul di rumah ortu. Masih menjalani komunikasi baik, masih sering kumpul-kumpul di rumah ortu, bercanda dalam tata bahasa tidak ada perbedaan (Agung Dewi, 7 Juli 2020).

Tidak jauh berbeda dengan hubungan keluarga asal, hubungan harmonis berhasil dijalin Agung Dewi terhadap keluarga suami. Hal ini didukung oleh latar belakang keluarga Made Tresna yang multikultur dimana ayah Made Tresna laki-laki Hindu-Bali sedangkan ibu Made Tresna adalah perempuan Muslim-Jawa. Perbedaan kultur ini berdampak pada adanya toleransi yang kuat.

Hubungan sama keluarga suami baik banget. Mendiang ibu mertua pengertian ya, selama menikah itu gak pernah sih berantem gak kaya orang lain yang tante dengar ya antara mertua dan menantu beda pendapat. Tante merasa diterima dengan baik (Agung Dewi, 7 Juli 2020).

Penyesuaian diri Agung Dewi terhadap turunnya kasta tidak dirasakan terlalu sulit terutama karena adanya rasa pengertian dan kasih yang ditunjukkan oleh keluarga Made Tresna. Agung Dewi merasa nyaman tinggal bersama kedua mertua dan satu kakak ipar perempuannya tanpa pernah mengalami konflik yang berarti. Hal ini setidaknya telah mengurangi satu beban yang harus ditanggung oleh perempuan nyerod.

\section{Kasus 2 - Agung Kencana}

Keputusan Menikah Nyerod

Agung Kencana lahir dalam keluarga dengan kasta Ksatria. la adalah anak keempat dari lima bersaudara. Tiga saudara tertua Agung Kencana adalah perempuan, sedangkan adiknya adalah laki-laki. Ketiga kakak perempuannya telah menikah lebih dulu dengan laki-laki berkasta di bawahnya dan mengalami konsekuensi nyerod. Berangkat dari pengalaman anak-anaknya yang lain yang tidak melalui prosesi lamaran, orang tua Agung Kencana melarang Agung Kencana menikah dengan lelaki berkasta lebih rendah.

Saat duduk di SMA, Agung Kencana mengenal Ketut Yasa, lelaki PNS lulusan S1 Ekonomi yang kini menjadi suaminya. Saat itu, mereka berteman karena sama-sama bersekolah di kecamatan. Agung Kencana menyadari bahwa Ketut Yasa menyukainya sejak SMA. Sayangnya, mereka berdua berbeda kasta: Jika Agung Kencana dari kasta Ksatria sedangkan Ketut Yasa berasal dari kasta Sudra. Oleh karena itu, saat orang tua Agung Kencana menjodohkan dirinya dengan laki-laki lain, Agung Kencana memilih menikah dengan lelaki pilihan orang tuanya. Sayangnya, pernikahan Agung Kencana ini kandas. Gagal dengan pernikahan pertamanya, Agung Kencana akhirnya menjalin hubungan asmara dengan

Jurnal IImu Sosial dan Humaniora | 374 
Ketut Yasa yang, karena tak mampu melupakan Agung Kencana, memilih membujang. Sayangnya, hubungan mereka tetap tidak direstui oleh orang tua Agung Kencana: walau pernikahan pertama putrinya telah kandas, orang tua Agung Kencana tetap bersikukuh melarang anaknya menjalin hubungan dengan pria berkasta lebih rendah. Dihadapkan pada kekerasan hati kedua orang tuanya, Agung Kencana, yang saat itu sudah berusia 28 tahun, nekat mengambil jalan pintas dengan sengaja hamil di luar nikah lalu kabur satu minggu untuk melangsungkan pernikahan:

Hmmm... sebenarnya cara bibi berdosa banget ya. Bibi memutuskan untuk kabur seminggu dari rumah untuk menikah karena bibi sudah hamil. Hanya itu cara yang sempat bibi pikirkan agar dapat menikah dengan suami (Agung Kencana, 24 Juli 2020).

Akibatnya, perjalanan hubungan Agung Kencana dan Ketut Yasa hingga pernikahan pun penuh liku dan butuh penyesuaian diri secara berkesinambungan.

\section{Penyesuaian Diri dengan Status Sosial Baru}

$\begin{array}{lcr}\text { Agung } & \text { Kencana menanggung } \\ \text { beragam } & \text { konsekuensi } \\ \text { keputusannya } & \text { menikah nyerod: }\end{array}$
pernikahannya tidak dihadiri oleh orang tua, ia menjalani upacara pati wangi, ia tidak lagi menikmati penghormatan istimewa, ia tidak lagi mendapat tempat duduk khusus dalam acara-acara adat, dan ia mengalami pengurangan jumlah tusuk sate. Hubunganya dengan orang tua-nya pun menjadi renggang. Di sisi lain, orang tua Agung Kencana juga merasakan dampak atas keputusan yang anak-anak perempuannya menikah nyerod:

Pertama orang tua kehilangan prestisenya di masyarakat ya karena keempat anak perempuannya nyerod. Ya terus orangorang yang biasanya hormat dan berbahasa Bali halus jadi biasa saja. Ya banyak keistimewaan yang hilang. Tapi tidak membuat bibi menyesal (Agung Kencana, 24 Juli 2020).

Walaupun mengalami beragam konsekuensi negatif, termasuk menyaksikan orang tua menanggung beban yang sama, Agung Kencana menerimanya. Keikhlasan menerima segala risiko yang menghampirinya membuat Agung mampu mejalani mempertahankan pernikahan yang sekarang sudah memasuki usia 15 tahun. Hal ini bukan hal yang mudah dijalani namun perhatian dan dukungan yang diberikan oleh suami dan keluarganya membuatnya mampu menyesuaikan diri dengan status barunya. Di bawah akan diurai lebih lanjut faktor yang mendukung dan juga penghambat penyesuaian diri yang dilakukan oleh Agung Kencana.

\section{Penyesuaian Diri dalam Pernikahan}

Pangkat Ketut Yasa tidak terlalu tinggi di tempat kerja. Penghasilan Agung Kencana dari berjualan pun juga tidak menentu. Padahal mereka punya banyak tanggungan ekonomi. Kondisi tersebut tidak membuat kualitas pernikahan Agung Kencana dan Ketut Yasa buruk. Dengan mengelola keuangan secara efektif, Agung Kencana mampu memenuhi berbagai 
kebutuhan dasar, seperti makan dan minum, perawatan rumah, pendidikan anak, dan dana cadangan untuk anggota keluarga yang jatuh sakit.

Cinta bukan hanya soal ekonomi dan seks, tetapi juga soal cita-cita sentimental, kasih sayang, dan sikap saling peduli seumur hidup. Ini semua menjadi dasar bagi Agung Kencana dan Ketut Yasa dalam menjalani kehidupan rumah tangganya. Meskipun sempat terbentur kesulitan untuk bersatu, memiliki banyak perbedaan dalam pengalaman dan masa silam, dan mengalami rasa tertekan, Agung Kencana dan Ketut Yasa berhasil bertahan sampai sekarang dan menyatakan bahwa mereka berbahagia. Di samping rasa saling percaya di antara mereka, kesabaran suami pada dirinyalah yang membuat Agung Kencana mudah menyesuaikan diri dalam pernikahan keduanya:

Perjuangannya, kesabarannya buat mendampingi bibi itu luar biasa sekali ya buat bibi. Rumah sekarang jadi tempat paling nyaman dan aman buat bibi. Memang dia lebih banyak diem tapi tetap kerasa perhatian dan romantisnya (Agung Kencana, 24 Juli 2020).

Bagi Agung Kencana, cinta adalah kemauan untuk menerima pasangan apa adanya dan Ketut Yasa mampu membuatnya merasa demikian. Tidak ada harapan yang muluk-muluk bagi Agung Kencana. Berbeda dengan pernikahan pertamanya, yang memaparkannya pada kekerasan dalam rumah tangga, pernikahannya yang sekarang membuat ia merasa sangat bahagia dalam menjalani hari-hari bersama keluarganya.
Penghambat Penyesuaian Diri: Trauma Kekerasan dalam Rumah Tangga

"Menikah bukan tanda akhir bahwa pasangan kita adalah jodoh kita. Mungkin, kita bisa dipertemukan jodoh kita di pernikahan kedua [...]" itulah ucapan Agung Kencana dalam wawancara tanggal 12 Agustus 2020 silam. Ucapan Agung ini merupakan klarifikasi atas sebab perceraiannya dengan suami pertamanya yang sering melakukan kekerasan dalam rumah tangga. Pengalaman buruk ini kadang masih berpengaruh: "Kadang bibi ya takut gitu, malem-malem kadang suka kebangun kebayang sama yang bibi alami dulu" (24 Juli 2020). Pernyataan Agung Kencana ini dibenarkan oleh Ketut Yasa:

Iya awal-awal menikah itu dia [Agung Kencana] sering kebangun. Awalnya om kira efek dari hamil ya, tapi ya cukup sering dan mengganggu. Kata dokter kandungannya karena stres, awalnya gak mau ngaku tapi akhirnya dia cerita kalau masih suka keinget sama kekerasan yang dialaminya (Ketut Yasa, 27 Juli 2020).

Pengalaman masa lalu yang bersifat traumatis terkadang membuat Agung Kencana merasa bahwa ia takut kejadian tersebut akan terulang. la juga sering merasa rindu akan ketiga anak buah pernikahan dengan suami pertamanya yang saat ini tinggal bersama mantan suaminya. Hal ini sedikit menyulitkan penyesuaian diri dari Agung Kencana pada pernikahan keduanya bersama Ketut Yasa.

Jurnal IImu Sosial dan Humaniora | 376 
Faktor Pendukung Penyesuaian Diri: Keluarga Asal dan Suami Suportif

Agung Kencana kini tinggal di rumah mertua, bukan hanya bersama suami dan kedua putranya serta ayah dan ibu mertua, tetapi juga dengan adik dari ayah mertua, sepupu suaminya beserta istri, dan dua kemenakan. Meskipun tinggal dengan banyak orang dalam satu lingkungan, Agung Kencana tidak berkeberatan. la merasa nyaman saja karena keluarga suaminya menerimanya dengan baik.

Selama ini gak pernah [konflik] sama sekali. Semoga engga yaa. Ipar juga sama ponakan baik-baik, sering bawain jajan atau mainan buat anak-anak. Gak pernahlah yang sampai kita dengki-dengkian itu gak pernah. Bener-bener semua diomongin apaapanya jadi yaa miskom gitu ga adalah (Agung Kencana, 24 Juli 2020).

Keluarga suami bahkan tetap menggunakan bahasa Bali halus singgih jika berkomunikasi dengan Agung Kencana. Status janda dengan tiga anak yang tersematkan padanya juga tidak dipermasalahkan oleh keluarga suami. Agung Kencana justru mendapat dukungan moril dari keluarga suami karena pengalaman buruk yang pernah menimpanya. Dukungan ini membuat Agung Kencana lebih mudah dalam menyesuaikan diri setelah nyerod.

Hubungan dengan keluarga asal yang sempat konflik pun berangsur membaik terutama setelah lahirnya anak pertama Agung kencana.

Sudah membaik ya, sejak kelahiran anak pertama. Awalnya cuek, tapi sekarang malah ditanya terus kapan main ke rumah tu niang [nenek] dan tu kakiang [kakek] ungkap
Agung Kencana (Agung Kencana, 24 Juli 2020).

Dari paparan di atas, dapat disimpulkan bahwa penerimaan dan dukungan dari keluarga besar serta kelahiran anak adalah faktor yang membantu penyesuaian diri subjek dalam pernikahannya. Di samping itu, kehadiran anak juga mampu menghubungkan kembali subjek dengan orang tuanya.

\section{Kasus 3 - Gusti Ani}

Memutuskan Menikah Nyerod

Gusti Ani adalah anak bungsu dari lima bersaudara dan satu-satunya perempuan yang terlahir dari keluarga berkasta Ksatria. Ibunya dan almarhum ayahnya keduanya berasal dari kasta Ksatria. Almarhum ayah Gusti Ani adalah salah satu tokoh masyarakat di desanya sehingga keluarganya disegani masyarakat desa. Meskipun keluarga Gusti Ani berpandangan modern dan fleksibel tentang kasta, mereka masih cukup serius dalam mempertimbangkan pandangan masyarakat.

Gusti Ani menikah dengan Komang Tana ketika ia berusia 26 tahun. Kini pernikahannya sudah berusia 18 tahun. Gusti Ani mengenal Komang Tana sewaktu kuliah di Malang. Komang Tana tujuh tahun lebih tua dari Gusti Ani.

"Ya sudah, kan terlihat langsung dari namanya I Komang. Wah sudah sadar itu kalau tidak sekasta, hehehhe", ungkap Gusti Ani (5 Juni 2020).

Menyadari bahwa hubungan berbeda kasta tidaklah mudah, Gusti Ani memilih untuk menjauh dari Komang Tana. Namun Komang Tana pantang 
menyerah. la terus berusaha mendekati Gusti Ani, mengantarnya berkuliah, mengikuti kegiatan organisasi, ke pura, dan lain-lainnya. Perhatian Komang Tana akhirnya meluluhkan Gusti Ani dan memantapkan hatinya untuk mengenalkan Komang Tana pada orang tua. Tindakan Gusti Ani memperkenalkan seorang pacar yang berkasta lebih rendah atau setara kepada orang tua ini merupakan tindakan yang dilarang adat. Oleh karenanya, Gusti Ani pun harus melanjutkan hubungan pacarannya ke jenjang pernikahan. Begitu lulus kuliah, Gusti Ani dipaksa menikah:

Ya pas bibi membawa suami yang waktu itu masih pacar ke kampung. Niatnya ya cuma mengenalkan biasa. Tapi ternyata tidak boleh. Langsung disuruh menikah. Agak kaget juga karena ya waktu itu bibi baru lulus dan belum ada niat untuk menikah (Gusti Ani, 5 Juni 2020).

Jadi, pernikahan Gusti Ani berawal dari kekurangpahamannya atas adat istiadat yang berlaku di Bali. Akibatnya, ia harus menanggung ketidaktahuannya tersebut dengan lelaki berkasta lebih rendah darinya.

\section{Penyesuaian Diri dengan Status Sosial Baru}

Setelah menikah, Gusti Ani mengalami banyak perubahan, utamanya dengan peran barunya sebagai ibu rumah tangga. Jam tidurnya berkurang karena ia harus memasak dan memikirkan bukan hanya keluarga asalnya tetapi juga keluarga suami. Namun, setelah ia memperoleh pekerjaan, beban hidupnya berkurang, sebab ia merasa bisa mengatasi rasa bosan dan bersosialisasi dengan lebih banyak orang.

$$
\text { Penyesuaian diri dalam }
$$

pernikahan berarti bahwa orang memandang diri sendiri dan masyarakat sebagai sebuah kolektivitas. Kadang, sebagai perempuan yang sudah nyerod, Gusti Ani mengalami kesulitan dalam menjelaskan kepada putra-putrinya mengapa mereka harus memanggil para anggota keluarga asalnya dengan awalan tu. Ketika Gusti Ani menjalani upacara matatah (potong gigi) bersama dengan keluarga asalnya, ia harus menerima kenyataan bahwa tempat tidurnya ditandai dengan posisi lebih rendah dari posisi anggota-anggota keluarga lainnya.

Anak-anak sempat tanya pas di kampung. Awal-awal mereka udah besar dan udah bisa bertanya ini itu. Katanya, kenapa kok sepupu-sepupunya bisa langsung manggil niang [nenek], bibi, dan aji [paman]. Sedangkan mereka kan harus di awali dengan tu. Bahkan ke sepupunya juga manggilnya tu padahal seumuran dan ada yang lebih muda dari dia. Panjang itu menjelaskannya agar mereka paham (Gusti Ani, 24 Juli 2020).

Meskipun banyak risiko yang harus dihadapi dan tidak mudah. Namun, Gusti Ani yakin bahwa cinta adalah perjuangan. Selama Komang Tana ada di sisinya dan mencintainya, Gusti Ani yakin ia mampu menanggung segala konsekuensi nyerod.

\section{Penyesuaian Diri dalam Pernikahan \\ Menjalani kehidupan berumah tangga, Gusti Ani dan Komang Tana sempat menjalani long distance marriage karena tuntutan pekerjaan.}


Kondisi ini membuat mereka sempat hidup terpisah dari anak-anak mereka. Ada suatu masa ketika Gusti Ani tinggal di Sidoarjo, suaminya di Jakarta, dan anak-anak di Bali. Untuk menyiasati jarak, mereka berkomunikasi dengan telepon dan berkumpul enam bulan sekali di hari raya Galungan.

Perbedaan usia yang cukup jauh menciptakan beberapa perbedaan antara Gusti Ani dan Komang Tana dalam hobi, pandangan dan cara menyikapi masalah. Itu sebabnya sampai kelahiran anak pertama mereka, Gusti Ani dan Komang Tana sering berdebat. Namun, lambat-laun, mereka akhirnya mencapai titik-titik temu, yaitu setelah mereka saling beradaptasi sampai merasa saling cocok dan saling takut kehilangan.

Kan usia bibi sama suami itu jauh ya. Ibaratnya bibi masih kekanak-kanakan ya apalagi belum sempat bekerja, senangsenang dengan diri. Jadi bawaannya sensitif. Syukurnya suami mau ngalah dan pelan-pelan menuntun. Suami sabar dan ngebantu banget sampai akhirnya bibi dapat kerja dan mulai bisa beradaptasi. Pokoknya kesepakatan apapun yang terjadi harus komunikasi, jangan diam-diam, gak menyelesaikan masalah (Gusti Ani, 24 Juli 2020).

Topik penting dalam komunikasi Gusti Ani dan Komang Tana adalah soal finansial. Di awal pernikahan mereka, mereka merasa cemas karena pangkat Komang Tana masih rendah dan Gusti Ani belum bekerja. Namun, keadaan finansial mereka kini sudah sangat baik. Di awal pernikahan mereka, mereka dan anak-anak mereka tinggal di rumah mertua Gusti Ani. Namun, sekarang mereka sudah memiliki rumah sendiri untuk keluarga kecil mereka.

Faktor Penghambat Penyesuaian Diri: Munculnya Rasa Penyesalan

Meskipun bahagia karena dapat menikah dengan orang yang dicintai dan mencintainya tidak dapat dipungkiri ada perasaan menyesal dalam benak Gusti Ani. Gusti Ani merasa menyesal jika teringat bahwa ia langsung menikah setelah lulus kuliah sebagai konsekuensi dari tindakannya mengenalkan suaminya-yang waktu itu masih pacarnya dan belum bekerjakepada keluarganya. la sedih ketika pernikahannya tidak dihadiri oleh ibunya. la juga bersusah hati karena tidak mengalami proses lamaran.

lya menyesalnya karena nikahnya keburuburu ya, bibi juga belum bekerja. Bosan di rumah terus. Sedangkan bibi kan anaknya suka kesana-kesini. Terus ya ada perasaan menyesal karena anak perempuan satusatunya tapi gak di lamar. Menyesal karena gak bisa membawa ibu ke hari bahagia bibi (Gusti Ani, 24 Juli 2020).

Lambat laun perasaan menyesal tersebut memudar karena Gusti Ani mencoba ikhlas. la menganggap bahwa itu sudah menjadi takdirnya. Gusti Ani pun menerima segala risiko yang harus dia hadapi atas keputusannya menikah dengan Komang Tana.

Faktor Pendukung Penyesuaian Diri: Fleksibilitas Keluarga Asal dan Suami

Begitu menikah, Gusti Ani tinggal bersama kedua mertua dan kakak iparnya. Meskipun sempat merasa terpaksa menikah, dukungan, perhatian dan semangat yang diberikan ibu dan keempat kakak laki-laki Gusti Ani

Jurnal IImu Sosial dan Humaniora | 379 
membesarkan hatinya. Di samping dukungan dari keluarga asal, dukungan juga diberikan oleh keluarga suami. Keluarga suami bahkan menghormati Gusti Ani yang berasal dari kasta Ksatria. Kondisi-kondisi tersebut membantu Gusti Ani dalam menyesuaikan diri dengan status sosial barunya:

Bibi awalnya takut tinggal di rumah orang kan hitungannya, tapi ternyata bibi senang. Bibi dihormati malah masih pakai bahasa halus Iho. Bibi yang gak bisa apa-apa juga [pekerjaan rumah] gak di omongin jahat, tapi di tuntun gitu. Ngerasa di sayang lah (Gusti Ani, 24 Juli 2020).

Setiap keluarga memiliki etika, tradisi dan budaya masing-masing. Meskipun berasal dari kasta berbeda, keluarga Komang Tana hangat, toleran dan tetap menghormati Gusti Ani meskipun ia sudah nyerod. Hal ini turut menguatkan Gusti Ani dalam mengatasi kegalauan hatinya akibat nyerod.

Pas tahu kalau om menikah dengan Bi Ani, memang berat di dia ya karena notabene dia belum siap untuk itu. Karena memang om dan keluarga om paham itu, kami berusaha untuk memperlakukan Bi Ani dengan baik agar kerasan dan betah tinggal di rumah. Syukurnya dia betah ya akhirnya dan bisa survive sama keadaannya (Koman Tana, 10 Juni 2020).

Sejauh ini Gusti Ani sering mempertemukan kedua keluarga untuk menghabiskan waktu bersama atau Gusti Ani menyebutnya "family time". Hubungan harmonis yang terjalin dengan keluarga asal atau suami memudahkan Gusti Ani menyesuaikan diri dengan status barunya sebagai istri, ibu, dan perempuan nyerod.
Dua tahun ke belakang Gusti Ani tinggal di rumah sendiri bersama suami, dua anak kandung, dan satu kemenakan. Anak pertama Gusti Ani dan Komang Tana adalah laki-laki dan berusia 18 tahun, sedangkan anak kedua adalah perempuan dan berusia 12 tahun. Sebelumnya, Gusti Ani tinggal bersama kedua mertua dan kakak iparnya. Namun Gusti Ani mengungkapkan bahwa tidak pernah ada perselisihan yang terjadi.

\section{Kasus 4 - Gusti Tari}

Keputusan Menikah Nyerod

Pertemuan Gusti Tari dan Putu Musa bermula di sebuah pameran di universitas tempat mereka berkuliah. Putu Musa adalah lulusan program Sastra Inggris di universitas yang sama dengan Gusti Tari. Mula-mula, Gusti Tari sebenarnya menaruh hati pada sahabat Putu Musa. Sebaliknya, sejak awal Putu Musa sudah tertarik pada Gusti Tari. Sebelum menikah, Gusti Tari dan Putu Musa telah tiga tahun berpacaran. Dua tahun pertama mereka jalani secara sembunyi-sembunyi.

Hubungan Gusti Tari dan Putu Musa bukan hanya ditentang oleh keluarga Gusti Tari karena beda kasta dan karena latar belakang pekerjaan Putu Musa. Hubungan mereka juga ditentang oleh keluarga Putu Musa. Ibu Putu Musa ingin anak lelaki semata wayangnya itu memperistri seseorang dengan melalui proses lamaran yang megah. Meski sempat ditentang oleh keluarga kedua belah pihak, Gusti Tari memantapkan hati untuk menikah dengan Putu Musa.

lya sempat ditentang sama kedua keluarga ya. Berat banget. Kita backstreet. Sampai Jurnal IImu Sosial dan Humaniora | 380 
akhirnya setelah lulus kita berdua langsung dapat kerja. Suami juga langsung ngelamar ya tapi ngelamar pribadi, maksudnya cuma berdua ke tante. Ya gak mikir panjang lagi tante terima karena selama ini anaknya baik, bertanggung jawab dan terasa sayang sama tante (Gusti Tari, 20 Agustus 2020).

Keyakinan akan kasih sayang yang diberikan Putu Musa membuat Gusti Ani yakin untuk mengarungi bahtera rumah tangga dengannya, meski harus melepas kastanya.

\section{Penyesuaian Diri dengan Status Sosial Baru}

Bagi seorang perempuan HinduBali berkasta triwangsa tentu sudah menjadi asupan sehari-hari kalimat untuk menikah dengan laki-laki yang sekasta atau kasta yang lebih tinggi. Memutuskan menikah dengan konsekuensi nyerod menjadi tantangan tersendiri karena menentang aturan adat yang berlaku. Namun Gusti Tari ikhlas menjalani risiko yang harus dihadapinya sebagai perempuan nyerod. "Cinta adalah permakluman. Tidak ada manusia yang sempurna. Namun, di situlah cinta berperan untuk dapat memaklumi semua kurang dan lemahnya", ungkap Gusti Tari pada 12 September 2020. Gusti Tari tidak menyesal menanggung berbagai konsekuensi negatif dari pernikahan nyerod: pernikahannya tidak dihadiri oleh orang tua; ia menjalani upacara pati wangi; ia tidak lagi menikmati penghormatan istimewa; bahkan harus menerima perlakuan tidak adil dari orang tuanya.

\section{Penyesuaian Diri dalam Pernikahan}

Ketika berusia 24 tahun, Gusti Tari menikah dengan Putu Musa. Kini pernikahan mereka telah memasuki usia 11 tahun. Gusti Tari dan Putu Musa telah memiliki seorang putri berusia 5 tahun. Sebelum pandemi COVID-19, Putu Musa adalah salah seorang manajer di sebuah hotel. Putu Musa baru menjabat sebagai manajer selama 8 bulan. Namun, pandemi menyebabkan Putu Musa dirumahkan. Berkurangnya pendapatan secara signifikan dan meningkatnya biaya hidup di ibu kota mengakibatkan Gusti Tari, Putu Musa dan putri mereka meninggalkan rumah kontrakan mereka untuk tinggal di rumah orang tua Putu Musa. Syukurnya, Gusti Tari masih tetap bisa bekerja sehingga masih bisa memenuhi beberapa kebutuhan seharihari. Kondisi ini membuat rasa memiliki antara Gusti Tari dan Putu Musa semakin kuat.

Kayaknya dalam sebelas tahun menikah, ini cobaan terberat ya. Apalagi setelah punya anak. Pikirannya ya tertuju ke anak. Kalau tante dan suami gak makan sehari mungkin masih bisa. Tapi kalau anak sampai gak makan kan gak tega ya. Jadi sekarang orientasinya ke anak. Tante kagum sih sama suami. Dulu kan manajer hotel ya, tapi sekarang mau jualan bakso frozen dan anter hampir ke semua kabupaten di Bali dia mau (Gusti Tari, 20 Agustus 2020).

Gusti Tari dan Putu Musa sudah saling beradaptasi dan karena itu mereka tidak mengalami terlalu banyak konflik setelah menikah. Dalam ranah seksualitas, Gusti Tari dan Putu Musa saling terbuka. Mereka sepakat menunda memiliki anak dan mengutamakan usaha membangun 
karir di masing-masing pekerjaan. Hal ini masih berlangsung hingga sekarang. Masing-masing mencoba memahami kebutuhan satu sama lain melalui komunikasi terbuka agar kedua belah pihak merasa nyaman.

Gusti Tari dan Putu Musa pun masing-masing tetap memiliki me time jika ingin pergi dengan temannya untuk memenuhi hobi. Hal ini dirasa efektif dalam menciptakan hubungan harmonis antara kedua belah pihak. Masingmasing merasa dihargai, dihormati, dan diberikan rasa percaya. Hal ini memudahkan Gusti Tari untuk menyesuaikan diri dengan statusnya sebagai istri, ibu, perempuan nyerod, bahkan seorang individu sosial.

\section{Penghambat Penyesuaian Diri: Mengalami Ketidakadilan dari Orang Tua}

Gusti Tari harus menelan pil pahit ketidakadilan dari kedua orang tuanya. la menyesalkan kenyataan bahwa upacara pernikahannya tidak dihadiri oleh orang tua. Dalam upacara pati wangi, ia merasa bersalah karena gagal menjaga kehormatan orang tua.

Adik Gusti Tari, yang juga seorang perempuan nyerod, mendapat perlakuan berbeda. Di hari pernikahan adiknya, kedua orang tuanya hadir memakai riasan dan ikut mendampingi prosesi upacara pernikahan. Menyaksikan senyum semringah adik dan kedua orang tuanya, Gusti Tari menangis didampingi oleh suami dan anaknya. la merasa diperlakuan secara diskriminatif. Padahal, ia dan adik perempuannya sama-sama nyerod. la mencoba mengubur rasa sakit hati karena, bagaimanapun, mereka toh keluarga Gusti Tari. Ketidakadilan berulang ketika adik perempuan Gusti Tari yang lain menikah dengan lelaki berkasta setara, yaitu Ksatria, tetapi sang ibu tidak menghadiri prosesi upacara pernikahannya.

Nyesek aja gitu. Kenapa perlakuannya beda. Padahal kan sama-sama anaknya, sama-sama nyerod. Maksudnya kalau karena kasta ya harusnya adil. Pernikahan tante orang tua sama sekali gak hadir. Nah ini malah hadir dan membantu keluarga laki menyiapkan pernikahannya. Sedih, kecewa, marah (Gusti Tari, 12 September 2020).

Menurut interpretasi Gusti Tari, perbedaan perlakuan dari orang tuanya seperti terpapar di atas dipengaruhi oleh latar belakang profesi dari menantu. Putu Musa (23 Agustus 2020) menuturkan, "lya sempat ada perlakuan berbeda ke istri dan adiknya. Pas acara dia nangis ya kecewa pastinya ya". Meski nyerod, adik Gusti Tari yang mendapatkan perlakuan istimewa itu bersuamikan seorang dokter, yang menyandang nama belakang sebuah keluarga terpandang di Bali. Hampir semua anggota keluarga besar ini berprofesi dokter. Perilaku orang tua Gusti Tari yang telah menentang tradisi menjadi buah bibir dalam masyarakat desa. Ini menggoreskan luka di hati Gusti Tari. Meskipun demikian, Gusti Tari tidak menyesalkan keputusannya untuk menikah dengan Putu Musa karena ia melakukan itu demi cinta dan sebagai suami-istri mereka saling menerima.

Jurnal IImu Sosial dan Humaniora | 382 
Faktor Pendukung Penyesuaian Diri: Penerimaan Keluarga Asal dan Suami

Meskipun sempat ditentang oleh ibu mertuanya, Gusti Tari kini sudah diterima dengan sangat baik di keluarga Putu Musa. Apalagi sejak kelahiran anak pertamanya. Bahkan di saat Gusti Tari dan Putu Musa sedang mengalami konflik finansial akibat pandemi. Berkurangnya pendapatan secara signifikan dan meningkatnya biaya hidup di ibu kota mengakibatkan Gusti Tari, Putu Musa dan putri mereka meninggalkan rumah kontrakan mereka untuk tinggal di rumah orang tua Putu Musa.

Ini syukur ya ada keluarga suami. Karena kan tante dan suami kerja di kota. Ada rumah keluarga suami yang kebetulan dekat juga dengan tempat kerja. Sebelumnya memang inginnya bisa mandiri dulu, kontrak rumah. Tapi pandemi datang dan semua rencana berubah. Bahkan mertua sekarang sering bantu juga buat kebutuhan seharihari ya terutama jajan dan susu anak (Gusti Tari, 12 September 2020).

Tidak jauh berbeda dengan keluarga suami. Hubungan Gusti Tari dengan keluarga asalnya pun berangsur harmonis. Saat pandemi mereka saling bergotong royong untuk dapat bertahan. Orang tua Gusti Tari sering mengirimi hasil tani dan kebun dari kampungnya untuk membantu memenuhi kebutuhan pangan Gusti Tari, suami, dan anaknya. Dukungan dari kedua keluarga membuat Gusti Tari bersyukur dan dapat membantu menyesuaikan diri di tengah pandemi.

\section{Kasus 5 - Gusti Meitri}

Keputusan Menikah Nyerod

Gusti Meitri menikah dengan Gede Surya 10 tahun lalu ketika Gusti Meitri berusia 26 tahun. Gusti Meitri dan Gede Surya bersahabat sejak SMA. Gede Surya adalah cinta sekaligus kekasih pertama Gusti Meitri. Gusti Meitri telah menaruh hati sejak lama namun tidak memiliki keberanian mengungkapkan. Begitu pun dengan Gede Surya. Setelah lulus SMA Gusti Meitri dan Gede Surya langsung menerima pekerjaan. Gusti Meitri tetap di ibu kota provinsi Bali, namun Gede Surya harus pindah ke kota kabupaten lainnya.

Meskipun berbeda kota, hubungan keduanya tetap berjalan baik. Sampai suatu waktu ketika Gede Surya bersilaturahmi ke rumah Gusti Meitri, ia menyatakan perasaan cintanya. Gayung bersambut, Gusti Meitri pun menerima. Tidak banyak pertentangan karena telah bersahabat lama, kedua keluarga telah mengenal satu sama lain.

Orang tua malah senang sekali ya karena tahu ternyata dia [Gede Surya] orangnya. Karena kami mengenalnya dia laki-laki baik, cerdas, dan bertanggung jawab, perhatian juga ke tante maupun keluarga. Jadi gak perlu menunggu lama diminta untuk segera menikah karena usia juga sudah pas (Gusti Meitri, 21 Agustus 2020).

Meskipun tidak mengalami pertentangan di kedua keluarga, tidak di pungkiri Gusti Meitri tetap menentang adat yang berlaku. Konsekuensi ini pun senantiasa diingatkan oleh kedua orang tua Gusti Meitri. Namun hal itu tidak menjadi penghalang Gusti Meitri dan Gede Surya untuk mengarungi bahtera rumah tangga mereka.

Jurnal IImu Sosial dan Humaniora | 383 
Penyesuaian dengan Status Sosial Baru

Tidak jauh berbeda dengan para partisipan sebelumnya, Gusti Meitri merasa senang sekaligus sedih di hari pernikahannya. Di satu sisi, ia senang karena bisa menikah dan akan menghabiskan hari-harinya bersama Gede Surya yang nota bene adalah sahabatnya. Di sisi lain, ia sedih karena tidak dapat menyaksikan kebahagiaan orang tuanya.

Menyesal sih enggak ya. Cuma sedih aja pas orang tua ternyata beneran gak hadir. Cuma paman, bibi, dan beberapa sepupu. Meskipun udah tahu dari awal tapi pas ngejalaninnya lumayan berat dan sedih juga (Gusti Meitri, 21 Agustus 2020).

Perbedaan perlakuan pascapernikahan antarkasta yang paling dirasakan oleh Gusti Meitri adalah ketika ia berkunjung ke desa. la harus pandaipandai menempatkan diri. Ketika berkomunikasi dengan masyarakat di luar keluarga asal, ia harus berhati-hati dalam memilih kata. Meskipun adat mengharuskannya memanggil $t u$, ini tidak terlalu dipermasalahkan oleh keluarga asal Gusti Meitri. Namun, setelah ia nyerod, orang-orang berkomunikasi dengannya menggunakan bahasa Bali sehari-hari saja alih-alih bahasa Bali halus. Namun itulah risiko yang harus dijalani atas keputusannya dan Gusti Meitri ikhlas menjalaninya.

\section{Penyesuaian Diri dalam Pernikahan}

Setelah resmi menikah, Gusti Meitri tidak mengalami terlalu banyak perubahan. Gusti Meitri dan suami menjalani long distance marriage tetapi ini tidak terlalu mempengaruhi hubungan mereka karena sejak masa pacaran mereka telah terbiasa menjalani pola hubungan seperti itu. Di samping aktif menekuni olah raga muay thai, Gusti Meitri adalah seorang wanita karir. Dalam menyiasati hubungan jarak jauh, Gusti Meitri dan suaminya menyempatkan diri untuk melakukan voice call setiap malam dan menghabiskan waktu bersama di akhir pekan.

Intinya komunikasi ya. Meskipun berjarak, tapi kan sekarang teknologi udah pada canggih, nah kita memanfaatkan itu. Tiap malam pokoknya harus komunikasi lewat telepon atau video call. Keberadaan suami, itu jadi kekuatan sendiri buat tante meski virtual. Tapi sekarang pandemi kan dia di rumah terus meski sesekali ke klinik (Gusti Meitri, 14 September 2020).

Gusti Meitri tidak mengalami kesulitan berarti dalam mengatasi perbedaan dengan Gede Surya dalam kebiasaan, hobi dan pandangan. Kuncinya adalah karena telah lama terjalin persahabatan di antara keduanya. Meskipun begitu, pada awalnya mereka sempat saling canggung dalam ranah relasi seksual, mengingat bahwa mereka telah bersahabat lama. Akhirnya, mereka berhasil menjadi saling terbuka. Dalam menunggu datangnya buah hati, Gusti Meitri dan Gede Surya saling menguatkan, memberikan semangat, dan berlatih bersabar. Adaptasi finansial juga tidak menjadi masalah, sebab mereka sama-sama memiliki pekerjaan dan penghasilan.

Gusti Meitri berpandangan bahwa cinta itu ibarat tumbuhan: harus disiram, dipupuk dan diberi cahaya matahari

Jurnal IImu Sosial dan Humaniora | 384 
dengan takaran pas. Pandangan ini dan dukungan suami membuatnya mampu menerima segala konsekuensi dan tantangan yang menghampirinya.

\section{Penghambat Penyesuaian Diri: Tuntutan Segera Memiliki Anak \\ Dalam pernikahan mereka, Gusti} Meitri pernah berkonflik dengan keluarga Gede Surya. Konflik ini, yang berkecamuk pada tahun pertama dan kedua pernikahan mereka, terjadi karena Gusti Meitri tidak kunjung mengandung. Untungnya, Gede Surya membantu meyakinkan keluarga asalnya bahwa ia dan Gusti Meitri selalu berusaha. Dengan kata lain, Gusti Meitri tidak bersalah. Ketika memberikan wawancara untuk riset ini, Gusti Meitri sudah empat bulan mengandung anak pertamanya.

Sempat sih ya [mengalami konflik], awalawal menikah tante gak kunjung hamil. Nah itu kayak dipertanyakan terus ke tante. Tante jadi merasa disalahkan. Padahal tante juga ingin segera punya anak. Tante sampai sering nangis sendiri di kamar. Waktu suami tahu, dia coba jelaskan ke orang tuanya kalau kita berdua sehat memang belum dikasih sama Ida Sang Hyang Widhi Wasa (Gusti Meitri, 21 Agustus 2020).

Gede Surya menyetujui ungkapan Gusti Meitri.

"Ketika saya tahu kalau istri merasa tertekan karena dituntut untuk punya anak, saya coba bilang apa adanya, dan itu bisa bantu istri supaya gak disalahkan terus" (Gede Surya, 24 Agustus 2020).

Seusai Gede Surya menjelaskan keadaan mereka kepada orang tuanya, hubungan kembali membaik. Apalagi kini Gusti Meitri telah hamil. Usia kandungan Gusti Meitri saat wawancara berlangsung adalah empat bulan.

Faktor Pendukung Penyesuaian Diri: Keluarga Asal Suportif dan Penerimaan Keluarga Suami

Sampai saat ini pun keluarga asal senantiasa memberikan perhatian dan dukungan kepada Gusti Meitri. Saat mengalami konflik dengan keluarga suami perihal dirinya yang tidak kunjung hamil, keluarga asal selalu ada dan memberikan kekuatan agar Gusti Meitri tetap sanggup menghadapi kerikil yang menghampiri rumah tangganya. Hal ini tentu membantu Gusti Meitri agar dapat menyesuaikan diri sebagai menantu.

Meski sempat mengalami konflik di tahun pertama dan kedua pernikahannya dengan keluarga suami, saat ini hubungan Gusti Meitri dan keluarga suami telah berjalan harmonis. Setelah mendapat penjelasan dari Gede Surya, orang tuanya senantiasa mendampingi Gusti Meitri ketika menjalani program untuk mempercepat kehamilannya.

Sejak suami coba jelasin, orang tuanya mulai paham kalau kita juga sedang berusaha. Kita juga ingin segera punya anak. Nah sejak itu ibu mertua lebih perhatian sih apa yang jadi kebutuhan. Syukurnya juga karena pandemi ini ya suami di rumah terus. Jadi dikasihnya baru sekarang (Gusti Meitri, 14 September 2020).

Dukungan kedua keluarga dalam perjalanan Gusti Meitri mendapat cobaan yang berat mampu menguatkan Gusti Meitri dalam menjalani kehidupannya sebagai istri dan saat ini sebagai calon ibu.

Jurnal IImu Sosial dan Humaniora | 385 


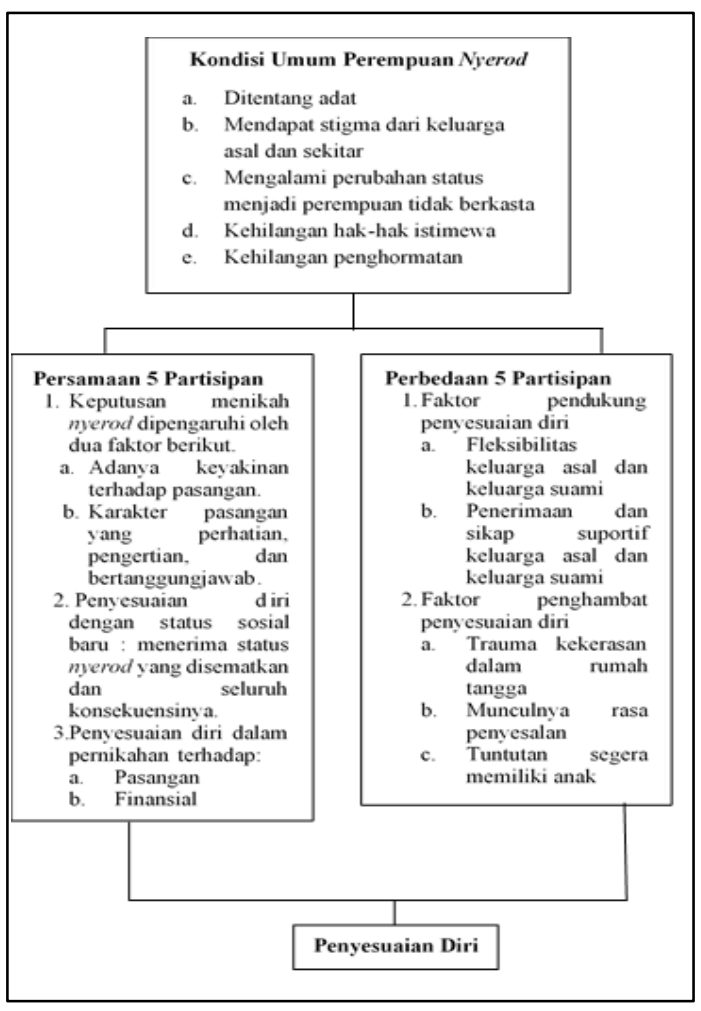

Gambar 1. Skema Hasil Penelitian

Hasil penelitian menunjukkan bahwa partisipan yang merupakan seorang perempuan harus menanggung akibat dari keputusannya nyerod seperti (1) tidak dilamar secara terhormat alih-alih hanya dijemput dan diajak ke rumah mempelai laki-laki; (2) di hari yang di hari yang seharusnya membahagiakan keluarga perempuan tidak diperkenankan untuk membuat pesta pernikahan; dan (3) menyapa anggota keluarga dengan awalan tu atau ratu sebagai bentuk hormat. Penurunan kasta dari Ksatria menjadi Sudra ditandai dengan upacara pati wangi untuk menghapus keharuman yang melekat pada kasta asal (Martha, 2018). Hilangnya beberapa hak sosial dapat menjadi beban psikologis bagi perempuan nyerod yang menuntutnya untuk melakukan upaya penyesuaian diri lebih berat dibanding tidak nyerod.

Hasil penelitian menunjukkan bahwa partisipan yang merupakan seorang perempuan harus menanggung akibat dari keputusannya nyerod seperti (1) tidak dilamar secara terhormat alihalih hanya dijemput dan diajak ke rumah mempelai laki-laki; (2) di hari yang seharusnya membahagiakan keluarga perempuan tidak diperkenankan untuk membuat pesta pernikahan; dan (3) menyapa anggota keluarga dengan awalan tu atau ratu sebagai bentuk hormat. Penurunan kasta dari Ksatria menjadi Sudra ditandai dengan upacara pati wangi untuk menghapus keharuman yang melekat pada kasta asal (Martha, 2018). Hilangnya beberapa hak sosial dapat menjadi beban psikologis bagi perempuan nyerod yang menuntutnya untuk melakukan upaya penyesuaian diri lebih berat dibanding tidak nyerod.

Perjalanan penyesuaian diri perempuan nyerod dipengaruhi oleh sifat identitas meliputi agama, budaya, dan kelas atau kasta (Shah et al., 2006). $\mathrm{Hal}$ ini sejalan dengan penelitian yang didasari oleh kesamaan partisipan dalam hal agama yaitu Hindu, budaya Bali, dan kasta Ksatria yang kemudian diharuskan turun kasta karena menikah dengan laki-laki yang berasal dari kasta Sudra yaitu kasta yang lebih rendah (nyerod). Perempuan nyerod dipengaruhi beberapa faktor lainnya yang meliputi kondisi saat perempuan memutuskan menikah nyerod; penyesuaian diri dengan status sosial barunya; penerimaan, dukungan, dan 
fleksibilitas keluarga asal dan keluarga suami; trauma masa lalu, munculnya rasa penyesalan, dan tuntutan dari sekitar.

Penyesuaian pertama dalam menikah nyerod adalah dengan pasangan. Menghabiskan sisa waktu hidup bersama orang asing yang tidak kita kenal sejak kecil bukanlah hal yang mudah. Tidak jarang konflik dari perbedaan sepasang suami istri dapat menimbulkan rasa frustrasi (Hurlock, 2014). Kelima partisipan menunjukkan rasa bahagia yang diperoleh dari hidup bersama orang yang dikasihi dan mengasihi pun kesetiaan pasangan. Penyesuaian terhadap finansial sebagai bentuk perlindungan dari ancaman fisik, sosial, dan gangguan kriminalitas tidak kalah penting (Nevid \& Rathus, 2016). Hasil penelitian menunjukkan komunikasi finansial dan pengelolaan finansial yang baik adalah kunci yang meliputi biaya berbagai kebutuhan, seperti pendidikan anak dan layanan medis bagi anggota keluarga yang sakit. Empat partisipan penelitian tidak mendapati masalah finansial. Salah satu partisipan yaitu Gusti Tari mengalami krisis dalam hal finansial yang diakibatkan oleh pandemi COVID-19. Tingginya kebutuhan yang tidak sebanding dengan pemasukan mengharuskan partisipan dan keluarga intinya (nuclear family) meninggalkan rumah kontrakan dan tinggal bersama orang tua suaminya.

Menikah bukan hanya penyatuan dua insan, namun juga dua keluarga. Penyesuaian diri dengan keluarga menyangkut budaya, etika, serta tradisi yang berlaku di dalamnya (Santrock, 2018). Fleksibilitas keluarga asal dan keluarga suami yang menerima dengan lapang dada keputusannya untuk nyerod sangat membantu Agung Dewi dan Gusti Ani untuk menyesuaikan dirinya setelah menikah. Meski keluarga asal sempat menentang keputusan Gusti Tari dan Agung Kencana untuk nyerod, lambat laun penerimaan dari keluarga asal mengurangi beban penyesuaian diri dari partisipan. Gusti Tari juga sempat mengalami pertentangan dari keluarga suami karena keinginan untuk dapat melakukan proses lamaran yang terhormat, tapi berkat kesabaran Gusti Tari dan suami, keluarga suami pun akhirnya menerima dan mendukung. Dukungan yang diberikan kelurga asal Gusti Meitri pun sanggup memberikan kekuatan untuk menghadapi tantangan terutama ketika ia menerima tuntutan untuk segera memiliki anak dari keluarga suaminya.

Penyesuaian diri pada pernikahan merupakan suatu proses adaptasi sosial dan psikologis dapat berupa penentuan diri (self determinant), pengalaman, konflik, kebiasaan, trauma (Yikar et al., 2019). Perceraian akibat kekerasan dalam rumah tangga yang pernah dialami Agung Kencana sempat menghantuinya di awal pernikahannya dengan Ketut Yasa yang menghambat penyesuaian dirinya. Munculnya rasa penyesalan yang dialami Gusti Ani karena dipaksa menikah cepat ketika belum bekerja, belum selesai menikmati masa mudanya, dan perasaan bersalah terhadap ibu dan almarhum ayahnya karena nyerod juga sempat menyulitkannya untuk dapat menyesuaikan dirinya pasca menikah. Rasa penyesalan yang dialami oleh 
perempuan nyerod setelah menikah merupakan hal yang dapat menghambat penyesuaian diri secara psikologis (Arisandi, 2015).

Perempuan nyerod dapat menyesuaikan diri secara optimal ia sudah mencapai titik temu antara kondisi dirinya dan tuntutan masyarakatnya (Yikar et al., 2019). Partisipan penelitian menunjukkan adanya penyesuaian terhadap status sosial baru dan konsekuensi yang harus dihadapi dari nyerod. Partisipan penelitian telah mampu membangun hubungan positif dengan pasangan, anak, keluarga asal, keluarga pasangan, maupun lingkungan sekitar sebagai dampak dari nyerod. Tujuan dan harapan hidup dari partisipan bahwa pernikahan yang dijalani adalah pernikahan terakhir dalam hidupnya dan bisa tetap saling mencintai menjadi motivasi dan pondasi kuat bertahannya pernikahan mereka. Tak luput meskipun telah menikah dan menjalani kehidupan yang baru partisipan tetap bertumbuh secara pribadi yang ditandai dengan karir yang tetap berjalan atau melakukan kegiatan pengembangan diri. Penerimaan diri, hubungan positif dengan orang lain, otonomi, penguasaan lingkungan, tujuan/harapan hidup, dan pertumbuhan pribadi merupakan dasar telah tercapainya kesejahteraan psikologis dari partisipan (Arisandi, 2015).

\section{SIMPULAN DAN SARAN}

Penelitian ini menunjukkan bahwa terdapat beberapa indikator dalam perjalanan penyesuaian diri partisipan dalam menikah dengan laki-laki yang memiliki kasta lebih rendah darinya.
Konsekuensi nyerod yang begitu berat dapat berpengaruh signifikan terhadap psikologis perempuan nyerod. Keputusan menikah nyerod yang didasari dari diri sendiri dan bukan paksaan tentu menjadi faktor utama yang menjadi landasan kekuatan penyesuaian diri partisipan.

Menerima status baru dan konsekuensi sebagai perempuan nyerod merupakan hal yang dilakukan partisipan untuk memudahkan langkahnya menyesuaikan diri setelah menikah. Selain itu penyesuaian dengan pasangan dan penyesuaian finansial juga tak kalah penting. Faktor pendukung penyesuaian diri perempuan nyerod adalah adanya dukungan dan penerimaan baik dari keluarga asal maupun keluarga suami. Beberapa faktor penghambat yang ditemui dari penelitian ini adalah adanya rasa penyesalan yang muncul akibat pernikahan nyerod, adanya trauma kekerasan dalam rumah tangga yang pernah dialaminya, dan tuntutan untuk segera memiliki anak.

Perempuan nyerod disarankan untuk tidak menganggap pandangan buruk masyarakat, perasaan berdosa dan perasaan durhaka kepada orang tua sebagai penghalang untuk menjadi seorang pasangan, orang tua, dan individu yang lebih positif, berbahagia menjalani kehidupan dengan keluarga, dan menciptakan lingkungan keluarga yang suportif. Memiliki keyakinan pada pasangan yang telah dipilih dan menjadikan pasangan sebagai support system dapat membantu menjalani berbagai konsekuensi nyerod.

Para peneliti selanjutnya disarankan untuk melakukan studi-studi 
yang dapat memperkaya pemahaman kita tentang latar belakang dan aspekaspek lain yang berkaitan dengan topik penyesuaian diri di kalangan para perempuan nyerod.

\section{DAFTAR PUSTAKA}

Alandari, K. J., \& Muti'ah, T. (2019). Konflik psikologis wanita nyerod dalam perkawinan adat di Bali. Jurnal Spirits, 10(1), 78-90. https://doi.org/10.30738/spirits.v10 i1.6540

Ariani, I. G. A. (2010). Marriage law and divorce based on adat law in Bali. Masalah-Masalah Hukum, 39(4), 297-301. https://doi.org/10.14710/mmh.39.4 .2010.297-301

Arisandi, V. (2015). Psychological wellbeing pada perempuan Hindu Bali yang mengalami turun kasta akibat perkawinan. Universitas Sanata Darma.

Creswell, J. (2014). Penelitian kualitatif \& desain riset. Pustaka Belajar.

Denzin, N. K., \& Lincoln, Y. S. (Eds.). (2017). Handbook of qualitative research (5th ed.). Sage Publication.

Deviga, S., \& Visalakshi, B. (2020). The reflection of new woman in Manju Kapur's a married woman and home. Journal of Natural Remedies, 21(7), 176-181. https://www.jnronline.com/ojs/inde x.php/about/article/view/420

Hodgetts, D., \& Stolte, O. M. (2012). Case-based research in community and social psychology. Journal of Community \& Applied Social Psychology, 22, 379-389. https://doi.org/10.1002/casp.2124
Hurlock, E. (2014). Psikologi perkembangan (5th ed.). Erlangga.

Mahardini, N. M., \& Tobing, D. (2017). Perempuan Hindu-Bali nyerod dalam melakukan penyesuaian diri. Jurnal Psikologi Udayana, 4(2), 390-398.

https://doi.org/https://doi.org/10.24 843/JPU.2017.v04.i02.p14

Martha, W. (2018). Posisi perempuan pada hukum Hindu dalam sistem vivaha samskara. Jurnal Widya Wertta, 1(2), 7-14.

Merriam, S., \& Tisdell, E. (2016). Qualitative research: $A$ guide to design and implementation. Jossey-Bass.

Nevid, J., \& Rathus, S. (2016). Psychology and the challenges of life: adjustment and growth (13th ed.). Hoboken.

Oka, I. G. (2000). Buku panduan percakapan tentang perkawinan adat Bali. Yayasan Sabha Sastra Bali.

Santrock, J. (2018). Adolescence (17th ed.). McGraw-Hill Higher Education.

Shah, G., Mander, H., Thorat, S., Deshpande, S., \& Baviskar, A. (2006). Untouchability in rural India. Sage Publication.

Snyder, C., \& Lopez, S. J. (Eds.). (2012). Handbook of positive psychology. Oxford University Press.

Weiten, W., Dunn, D. S., \& Hammer, E. Y. (2018). Psychology applied to modern life : adjustment in the 21st century (12th ed.). Cengage Learning.

Yikar, S., Doğan, S., Yurtseven, S., Arslan, S., \& Nazik, E. (2019). An assessment of marital adjustment

Jurnal IImu Sosial dan Humaniora | 389 
and sexual functions of women working in shifts in healthcare. Journal LIFE, 5(1), 73-88. https://doi.org/https://doi.org/10.20 319/lijhls.2019.51.7388 